\title{
Understanding the adoption of sustainable silvopastoral practices in Northern Argentina: what is the role of land tenure?
}

Article

Accepted Version

Tschopp, M., Ceddia, G., Inguaccio, C., Bardsley, N. and Hernandez, H. (2020) Understanding the adoption of

sustainable silvopastoral practices in Northern Argentina: what is the role of land tenure? Land Use Policy, 99. 105092. ISSN 0264-8377 doi:

https://doi.org/10.1016/j.landusepol.2020.105092 Available at https://centaur.reading.ac.uk/93098/

It is advisable to refer to the publisher's version if you intend to cite from the work. See Guidance on citing.

To link to this article DOI: http://dx.doi.org/10.1016/j.landusepol.2020.105092

Publisher: Elsevier

All outputs in CentAUR are protected by Intellectual Property Rights law, including copyright law. Copyright and IPR is retained by the creators or other copyright holders. Terms and conditions for use of this material are defined in the End User Agreement. 


\section{CentAUR}

Central Archive at the University of Reading

Reading's research outputs online 
4 Understanding the adoption of sustainable silvopastoral 5 practices in Northern Argentina: What is the role of land 6 tenure?

$8 \quad$ Highlights

9 - We study the adoption of sustainable silvopastoral practices in the Dry Chaco

10 - Various Multivariate Probit (MVP) models are used to assess adoption decisions

11 - Socio-economic factors influence adoption of all practices

12 - Affiliation with a producer organization is an excellent predictor of adoption

13 - The limited influence of land tenure can be explained by local specificities 
Understanding the adoption of sustainable silvopastoral practices

\section{Abstract:}

18 The Argentinian Dry Chaco has suffered from very high deforestation rates in the last decades, and forest 19 degradation remains an important issue. This study examines the adoption of sustainable silvopastoral 20 practices by smallholder households in the Chaco. Data for the study were collected from 393 families in 21 two municipalities of the Province of Salta. We used multivariate probit (MVP) models to assess land users' 22 decision to adopt three management practices. We show that socio-economic factors (household assets, 23 number of animals), human and social capital (literacy, affiliation with a producer organization), as well as 24 access to financial resources (credit) determine adoption. Secured land tenure also increases the likelihood 25 of adoption, but not as much as we initially hypothesized. We discuss how certain specificities of the area, 26 including difficulties accessing land titles and pressure from the agro-industry, as well as the characteristics 27 of the resource itself - forest grazing areas, some shared by multiple families - might explain this 28 unexpectedly low influence of land tenure on the adoption of sustainable silvopastoral practices.

31 Key Words:

32 Silvopastoral systems, adoption of sustainable practices, land tenure, Dry Chaco 


\section{Introduction}

Deforestation, land use change, and agriculture account for $23 \%$ of global greenhouse gas emissions and represent a significant share of the emissions of South American countries (Aide et al., 2013; Harris et al., 2012; Shukla et al., 2019). The Dry Chaco - the second largest forest ecoregion in Latin America - has experienced particularly rapid deforestation in recent years (Ceddia and Zepharovich, 2017; Grau et al., 2008; le Polain de Waroux et al., 2017; Volante et al., 2016). This process has largely been driven by agricultural expansion, with land use changing from forest to cropland or pastures (Fehlenberg et al., 2017; PiquerRodríguez et al., 2018).

Deforestation in the Chaco negatively affects forest users, particularly indigenous people and criollo smallholder farmers. Both groups use the forest's resources either directly or through employment. Indigenous people additionally rely on fishing and small-scale livestock ranching, while the main livelihood of criollo smallholder farmers gravitates around cattle ranching and off-farm employment, including work in construction or small shops and work migration to urban centres (Córdoba and Camardelli 2017).

Criollo smallholders and indigenous communities are particularly vulnerable to adverse effects of deforestation and agricultural expansion for commodity production - processes that are occurring throughout the Dry Chaco. Many smallholders and indigenous people have been displaced in recent years, or have lost access to common resources because of deforestation (Carr et al., 2009). These trends of exclusion not only heighten these groups' vulnerability, but also increase the pressure on remaining forest ecosystems by limiting the amount of land available to smallholders for grazing their herds, resulting in higher stocking 53 densities.

Criollo smallholders used to produce cattle in customary system known as campo abierto ("open field"). In this system, cattle are left to roam in the forest, feeding from trees, bushes, shrubs, and natural pasture, with limited supervision by the farmer (Camardelli, 2005). Almost half of all farms in our study region exclusively use the campo abierto system. Scholars have shown that pressure from small-scale cattle farming in Chaco forests can cause environmental degradation and alter the composition of landscapes and land covers in these forest ecosystems. Pressure from cattle has already resulted in changed forest composition, with bushes and shrubs encroaching on natural pastures (Grau et al. 2015). Finally, the Chaco forest, and in particular its arid and semi-arid regions, have been noted as being particularly prone to erosion (Therburg et al., 2019). This can be aggravated both by open-field grazing and by the advance of the agricultural frontier and the related deforestation.

Increasing the use of more sustainable agricultural practices that reduce land and forest degradation is therefore essential to preserving the Chaco. Forest restoration, including through sustainable agroforestry practices, has the potential to increase carbon sequestration while providing stable livelihoods. More specifically, sustainable silvopastoral practices can help to improve resilience as well as ecosystem services for both users and non-users of the forest (Hänsela et al., 2009). Adoption of new management practices in grazing systems has the potential to significantly lower the impact of smallholders' livestock herding while also reducing greenhouse gas emissions from this sector (Nieto et al., 2018). And, importantly, they could 
Argentina's National Forest Law (National Law № 26,331), passed in 2007, is aimed at addressing deforestation of native forests throughout the country. It identifies three land use categories for native forest: "red areas" are high-priority conservation zones, "green areas" may be used for productive purposes, and "yellow areas" are of medium conservation value. Each province of Argentina adopted their own regulations for the implementation of the forest law, with the province of Salta allowing a particularly high level of discretion on the range of activities allowed in yellow areas (Fernández Milmanda and Garay, 2019). As a result, deforestation rates remained high in the province over the period 2006-2016, even after the implementation of the forest law.

To address some of these challenges and at the same time offer smallholders options for improving their productivity and their resilience, the Argentinian State recently promoted a set of public policies for yellow areas, under the label Manejo de Bosque con Ganaderia Integrada ("Forest Management with Integrated Cattle Ranching"), MBGI for short (Peri et al. 2018). This national plan echoes previous policy initiatives in that it aims to reconcile conservation of native forests with smallholder production by allowing certain productive uses, including silvopastoral cattle production, in a considerable share of the remaining native forest (Borrás et al., 2017). Criollo smallholders are one of the main target groups of this policy and this policy urges each productive unit to issue a management plan following the following seven technical guidelines: 1) the management plan has to comply with existing policies and plans for Sustainable Management of Native Forests (forestry inventory, baseline, silviculture). 2) exclusive areas for biodiversity conservation have to be determined (at least $10 \%$ of the farm areas), 3) Shrub management and pasture introduction to provide forage to cattle; 4) implementing a monitoring system; 5) Livestock management and stocking rates control 6) contingency plans for droughts and/or fire and 7) water management to reduce impact of livestock on the forest (Alaggia et al., 2019; Peri et al., 2018). These seven guidelines are meant to be addressed through one or several management plans developed by smallholders. At the time of the survey (2018) MBGI was only implemented in a couple of pilot sites in the Province of Salta.Under this policy smallholders can therefore improve up to $70 \%$ of their land, by using introduced exotic grass species, and by removing some shrubs wither manually, or with a low-impact tractor roll. These improvements are however contingent on the approval of their management plan. In order to fully comply with the policy, smallholders would therefore have to adopt new management practices (e.g. enclosing some areas of their farm to avoid cattle intrusions in high-priority conservation areas). Further, such practices include rotational grazing, introduction of exotic grass species, and the removal of some types of thorny bushes and shrubs to create corridors for vegetation development (guideline number 3).Shrubs are not completely removed but are uprooted and broken down in smaller pieces in order to maintain soil cover. All of these methods are practised by some smallholders in the region, but up to now their use is not widespread. Understanding the adoption patterns of these existing practices is therefore crucial for a policy such as MBGI to be implemented successfully. Moreover, in spite of these current policy developments, scant attention has been paid to the specific socio-economic groups of criollo smallholders and indigenous people. The conditions for promotion of sustainable silvopastoral practices have likewise received little attention. To our knowledge, an analysis of the adoption of sustainable practices, including its drivers and adoption patterns, is currently lacking. Although there is a vast literature on the adoption of agricultural practices (soil and water conservation, sustainable agricultural practices, etc.), few articles examine what determines the adoption of silvopastoral practices. Our article addresses this research gap using the case of the Province of Salta, Argentina. We focus on three practices and assess 
Understanding the adoption of sustainable silvopastoral practices

114

115

116

different variables associated with their adoption. First, we summarize the existing literature on this topic. Next, we present our data and the methods used for their collection and analysis. Then we discuss the results obtained from our MVP statistical model. We conclude by summarizing our main insights.

\section{Adoption of agricultural technologies and silvopastoral practices: a literature review}

A rapidly growing body of case studies of the adoption of agricultural practices in the global South and North shapes our understanding of what enables effective transitions towards sustainability. Diffusion of information through social networks plays a key role in explaining the spread of a given practice (Banerjee et al., 2013; Rogers, 2003), along with the influence of state and non-state extension service actors (Garbach et al., 2012; Kassie et al., 2013). An important share of the literature focuses on the characteristics and attributes of households and individuals adopting different practices, comparing them with non-adopters. Understanding these patterns is essential to effectively targeting the diffusion of new practices. This section identifies key factors that are often used to assess the adoption of sustainable production practices.

There is a vast literature on the adoption of different practices by small-scale farmers in the global South. Recently, researchers have focused on the adoption of soil and water conservation technologies (Amsalu and de Graaff, 2007; de Graaff et al., 2008; Nkegbe et al., 2012; Tenge et al., 2004; Theriault et al., 2017; Zeweld et al., 2019), conservation agriculture (Baudron et al., 2009; Bijttebier et al., 2018; Garbach et al., 2012; Shetto and Owenya, 2007; Wauters et al., 2010), climate-smart agriculture (Kpadonou et al., 2017), and, more generally, sustainable intensification or sustainable agricultural practices (Kassie et al., 2015; Ndiritu et al., 2014; Nkomoki et al., 2018).

Many articles identify households' socio-economic characteristics as key determinants of the adoption of new practices, including household size and available labour force (de Graaff et al., 2008; Tenge et al., 2004), gender of the household head (Doss and Morris, 2001; Ndiritu et al., 2014; Theriault et al., 2017), and education (Nkomoki et al., 2018), among others.

Socio-economic status and financial capabilities are considered an important factor, as new technologies often require some level of capital investment in order to become effective. Accordingly, scholars have been assessing the importance of having a bank account (Kleemann et al., 2014). Access to credit is also crucial, and is often an important predictor of the adoption of a new practices(Kassie et al., 2015; Smith et al., 2017; Zeweld et al., 2019), and a recent study showed that access to credit is a limiting factor for smallholders in the Dry Chaco (Mastrangelo et al., 2019). Several studies emphasize the importance of networks in diffusion and adoption patterns (Baumgart-Getz et al., 2012), although they rarely apply established social network analysis methodologies; one exception is Banerjee et al. (2013). Furthermore, social capital and particularly membership in a farmer association or cooperative is regularly stressed as a key factor in the adoption of new practices (Ferreira Gonzaga et al., 2019; Hänsela et al., 2009; Shetto and Owenya, 2007). The role of State extension services is likewise mentioned in several studies (Amsalu and de Graaff, 2007; Nkegbe et al., 2012). 
150 However, the factor that almost every adoption study addresses is land endowment or the size of the 151 available land, and more specifically the issue of land tenure.

152 Since the early work of Hardin (2009), it has often been argued that granting land ownership to smallholders 153 or resource users could help to improve management while avoiding the freeriding behaviour associated with 154 common resources or disputed land. Although Hardin's original argument has met heavy criticism (Ostrom 155 2009), his hypotheses are still very present in the literature on adoption of new agricultural practices.

156 It is often assumed that private land titles and secured land tenure should automatically lead to greater 157 investments by smallholder farmers. For instance, Nkomoki et al. (2018) show that land tenure plays an 158 important and positive role in the adoption of multiple sustainable agricultural practices. Similarly, Knowler 159 and Bradshaw (2007) found in a meta-study on conservation agriculture that land tenure was one of the most 160 important factors explaining technology adoption. The security of tenure that accompanies private ownership 161 is generally seen as important for adoption of agricultural technology. One could however argue that security 162 of tenure, is separable from private ownership (Ostrom, 2009), something that Hardin's article did not 163 recognize. For example, Cuba's innovations in the "special period", involved assigning exclusive "usufruct rights" to land held in common in state-owned cooperatives, thereby affording security of tenure without privatization (Wright, 2009).

Only a small portion of the existing literature on technology adoption focuses on agroforestry practices, and even less work exists on the adoption of silvopastoral practices. In this study, we understand agroforestry as denoting a land management system that includes trees in intercropping or pasture production. A silvopastoral system consists of livestock grazing in forest areas. Accordingly, we understand silvopastoral systems to be a specific form of agroforestry. A study by Latawiec et al. (2017) is one of the few exceptions. Their survey of $\mathbf{2 5 0}$ farmers in Matto Grosso revealed that labour availability plays a key role in the adoption of sustainable practices. They also show that several obstacles hinder the adoption of new practices, and that one of the main motivations for the adoption of such practices is the prospect of economic profitability and higher yields.

\section{Methods}

\subsection{Survey data collected}

The data for this analysis were collected in a survey conducted in the Dry Chaco in the Province of Salta, Argentina, in September 2018. Before administering the survey, we conducted qualitative interviews and identified three selected sustainable silvopastoral management practices: (1) sowing of introduced pastures on a small portion of the land for cattle grazing; (2) previous preparation of grazing land by manually removing shrubs; (3) fencing and rotational grazing. These practices are often combined, and they involve different labour and financial costs. Shrub removal is labour-intensive, but relatively cheap, while the other two practices require more financial means. The focus of this paper is not on assessing in detail the impact that these practices have on the ecosystem. Rather, our aim is to understand what drives the adoption of these practices and to describe the socio-economic characteristics of farmers using them. 
We conducted the survey in two municipalities of the departments of San Martín and Rivadavia. The survey focused on various socio-economic indicators (level of education, nutrition, household assets), land tenure and social capital indicators, as well as some additional information on agricultural production (number of animals, size of land, etc.) and agricultural practices. We interviewed 392 households in the two municipalities of Embarcación and Rivadavia Banda Norte. We chose these municipalities purposively because of the high level of conflicts recently experienced there, and because of their location near the "agricultural frontier", which we hypothesized to be associated with increased pressure on social-ecological systems. We also chose these municipalities because they contain a relatively high density of smallholder families, whereas there are fewer smallholder families in areas that have high deforestation rates. We applied a stratified random sampling, in which each municipality was divided into different geographical zones, which were selected randomly for inclusion in the survey. All households within the selected zones were interviewed. Table 1 summarizes the characteristics of our sample. We use descriptive statistics (mean and SD) to indicate the distribution of the variables of this study.

To account for socio-economic status, we constructed an asset-index through a principal component analysis, as suggested by the Filmer Pritchett method (Filmer and Pritchett, 2001). Our index was constructed using a polychoric principle component analysis (PPCA), following the methodology developed by Kolenikov and Angeles (Kolenikov and Angeles, 2009, 2004). The index ranges from 0 to 3 and reflects a portfolio of different assets that are quite common in the region. The different variables that are included in

204 the index model, are described in Annex A.

Table 1: Description of variables used

\begin{tabular}{|c|c|c|c|c|}
\hline Variable name & $\begin{array}{l}\text { Variable } \\
\text { Codes }\end{array}$ & Description & $\begin{array}{l}\text { Possible } \\
\text { answers }\end{array}$ & $\begin{array}{l}\text { Overall } \\
\text { Mean (SD) }\end{array}$ \\
\hline \multicolumn{5}{|l|}{ Dependent variables } \\
\hline Pastures & $\mathrm{P}$ & 1 if farmer sowed any pasture areas & binary & $0.42(0.49)$ \\
\hline $\begin{array}{l}\text { Manual shrub } \\
\text { removal }\end{array}$ & M & $\begin{array}{l}1 \text { if farmer engaged in manual } \\
\text { uprooting of shrubs }\end{array}$ & binary & $0.46(0.50)$ \\
\hline Fencing & $\mathrm{F}$ & 1 if farm is delimited with fences & binary & $0.42(0.49)$ \\
\hline \multicolumn{5}{|c|}{ Independent variables } \\
\hline \multicolumn{5}{|c|}{ Household characteristics } \\
\hline Municipality & MUNI1 & $\begin{array}{l}\text { Municipality ( } 1 \text { if Rivadavia Banda } \\
\text { Norte, } 0 \text { if Embarcaccion) }\end{array}$ & Binary & \\
\hline $\begin{array}{l}\text { Gender of } \\
\text { respondent }\end{array}$ & GENDER & Gender of household head, 1 if male. & Binary & $0.81(0.41)$ \\
\hline $\begin{array}{l}\text { Distance to closest } \\
\text { village }\end{array}$ & DIST & Distance to nearest village (in $\mathrm{km}$ ) & $\begin{array}{l}\text { integer } \\
(\mathrm{km})\end{array}$ & $29.29(17.08)$ \\
\hline Age of hh head & AGE & Age of household head & years & $55.31(15.43)$ \\
\hline Year established & YEAR & $\begin{array}{l}\text { Year the family established itself in the } \\
\text { region }\end{array}$ & years & $1955(36.44)$ \\
\hline
\end{tabular}




\begin{tabular}{|c|c|c|c|c|}
\hline Household size & SIZE & Number of people living in household & integer & $4.17(2.46)$ \\
\hline Literacy & LIT & 1 if every household head can read & binary & $0.92(0.27)$ \\
\hline $\begin{array}{l}\text { Socio-economic } \\
\text { status }\end{array}$ & SES & $\begin{array}{l}\text { Socio-economic status index (see } \\
\text { Annex A) }\end{array}$ & continuous & $1.04(0.74)$ \\
\hline \multicolumn{5}{|l|}{ Productive capital } \\
\hline Access to credit & CRED & $\begin{array}{l}1 \text { if household has access to credit or } \\
\text { subsidies (public programmes e.g. rural } \\
\text { development). }\end{array}$ & binary & $0.07(0.26)$ \\
\hline Number of Cows & cow & Number of cows household has & numeric & $43.41(63)$ \\
\hline $\begin{array}{l}\text { Off-farm } \\
\text { employment }\end{array}$ & OFF & $\begin{array}{l}1 \text { if one or more household members } \\
\text { are employed off-farm }\end{array}$ & binary & $0.33(0.47)$ \\
\hline \multicolumn{5}{|c|}{ Land tenure \& Social Capital } \\
\hline $\begin{array}{l}\text { Land tenure } \\
\text { security }\end{array}$ & LANDT & $\begin{array}{l}1 \text { if land tenure is secured (Property } \\
\text { titles (individual or communitary), or in } \\
\text { process. }\end{array}$ & binary & $0.43(0.49)$ \\
\hline Conflicts & CONFL & $\begin{array}{l}1 \text { if household reports conflict over } \\
\text { land }\end{array}$ & binary & $0.24(0.43)$ \\
\hline $\begin{array}{l}\text { Membership in a } \\
\text { producers' } \\
\text { organisation }\end{array}$ & SOC & $\begin{array}{l}1 \text { if household belongs to a civil society } \\
\text { organisation (including cooperatives) }\end{array}$ & binary & $0.44(0.49)$ \\
\hline Observations & $n$ & Number of observations & $\mathrm{n}$ & 392 \\
\hline
\end{tabular}

\subsection{Statistical model}

\subsubsection{Latent variable model}

In this paper, we use a latent variable framework to model the decision of various households to adopt selected silvopastoral practices as a binary outcome. We can describe the potential decision of a farmer to adopt a specific practice as follows:

Where $Y^{*}$ indicates the preference or perceived benefits of a farmer $i$ to adopt a specific silvopastoral from the following list: $P=$ introduction of introduced pastures, $M=$ Manual removal of shrubs and bushes, and $F$

219 = fencing (enclosure). In our model, the outcome is to be determined by observed household characteristics $220\left(X_{i}\right)$, as well as the error term. The unobserved preferences in Equation 1 translate into a binary outcome as 221 follows:

$$
Y_{i k}=\left\{\begin{array}{l}
1 \text { if } Y_{i k}^{*}>0 \\
0 \text { otherwise }
\end{array}\right.
$$


Understanding the adoption of sustainable silvopastoral practices

253

254

Figure 1: Model used in the study, including independent and dependent variables and interaction effects benefits exceed 0 .

\subsubsection{Single versus multiple practices adoption: a multivariate probit model} Earlier studies on adoption, including the work by Feder (1982), focused on the challenges of accounting for single technology using single binary dependent variables that include only one dependent variable they act as substitutes for each other (negative correlation, see e.g. Kpadonou et al. 2017).

In order to estimate simultaneously the determinants of the three practices considered within this study, we field of agricultural practices adoption (Kassie et al., 2012; Ndiritu et al., 2014; Nigussie et al., 2017; Teklewold et al., 2013b; Theriault et al., 2017; Ward et al., 2018). poses several challenges, because the dependent variables may be correlated. To address this issue, the MVP model provides estimates of error terms of the different models simultaneously. The main advantage of MVP models is that they do not require the formulation of assumptions of independence regarding the adoption patterns of specific practices. It is therefore highly adequate for addressing situations in which households might simultaneously adopt more than one practice, or might follow a differentiated or hybrid adoption pattern.

\subsubsection{Presentation of the model}

We reviewed the literature in order to identify factors that have been found to influence the adoption of different types of agricultural practices and technology (Barton et al., 2016; Hänsela et al., 2009; Kassie et al., 2015; Nigussie et al., 2017). The variables are classified into a) socio-economic factors, b) Productive capital and c) land tenure and social capital -or institutional characteristics. Figure 1 illustrates the basic the dependent variables.

Which means that a household will adopt a specific silvopastoral practice if their perceived preference or the adoption of multiple practices simultaneously. Single adoption models analyse the decision to adopt a (technology adopted). The adoption of more than one practice was commonly assessed by calculating several probit/logit models. However, in some cases the adoption of several agricultural technologies might be interdependent, either because the technologies complement each other (positive correlation) or because chose to apply a multivariate probit (MVP) model, following the suggestion of Cappellari and Jenkins (2003). This type of model has recently gained in efficiency by incorporating maximum likelihood estimators derived from simulations using Markov chain Monte Carlo methods. The procedure has been widely applied in the

MVP models address a key problem described by the adoption literature. Studying more than one practice features of our model and shows how the various types of independent variable influence the realization of 
Independent Variables

Productive capital

\begin{tabular}{|l|}
\hline Household \\
characteristics \\
and \\
Socio- \\
economic \\
factors \\
\hline
\end{tabular}
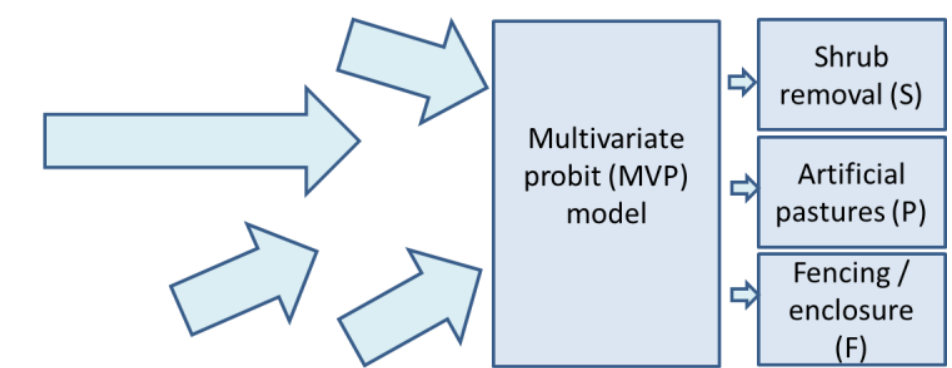

258

259

260

261

262

263

264

265

266

267

268

269

270

271

272

273

274

275

276

277

278

279

280

281

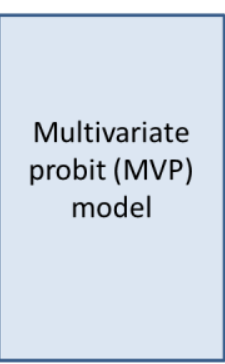

Dependent Variables

Social capital

Land tenure

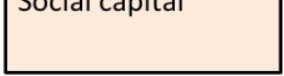

Prior to conducting the analysis, we formulated different hypotheses regarding adoption of sustainable silvopastoral practices, based on the existing literature:

(1) Age and distance to the nearest village are negatively associated with adoption of the practices.

(2) Socio-economic status, access to credit and subsidies, and affiliation with an organization are all positively associated with adoption of the practices.

(3) Land tenure is positively associated with adoption of the practices.

Hypotheses 1 and 2 reflect some of the most important determinants found in the literatures. Household characteristics such as age of household head and distance to the villages are associated with adoption. Further, a higher socio-economic status, access to credit and membership to a producers association can provide a household the necessary resources and knowledge required to invest in new agricultural practices. This hypothesis further reflects recent findings from the Dry Chaco region (Mastrangelo et al., 2019). Finally, our third hypothesis addresses the role of land tenure, which is often times found to have positive influence on the adoption of new agricultural practices. In order to test the above hypothesis we initially specify a first set of models (Model 1 ) in which the probability of adopting the various silvopastoral practices (namely, the implantation of introduced pastures $P$, the manual removal of shrubs $M$ and the introduction of fences $F$ ) depends on the following variables: municipality (MUNI1), distance to the closest village (DIST), socioeconomic status (SES), land tenure security (LANDT), existence of conflicts (CONFL), access to credit (CRED), number of cows (COW), year of establishment (YEAR), age of household head (AGE), gender of household head (GENDER), membership in a producers' organization (SOC), off-farm employment (OFF), literacy (LIT), household size (SIZE).

Subsequently, in order to test the robustness of the initial specification, we extend the model to account for a number of interactions. In Model 2, we include interactions between the geographical variable and the land tenure variable and the presence of conflicts over tenure respectively, namely MUNI1×LANDT and 
MUNI1 XCONFL. The assumption is that the effects of tenure and land related conflicts impact differently on 283 the adoption of silvopastoral practices, depending on the geographical location, because in one of the considered municipality (Embarcaccion), there is currently much more pression from the large-scale agribusiness. In Model 3, we account for interactions CRED×SOC, CRED×LIT and LANDT×CONF. Here the assumption is that the effect of credit on adoption is conditional on being part of a producers' organization and on the degree of literacy. Additionally, we assume that the effect of land tenure is conditional on the existence of conflicts. Finally, in Model 4, we account for interactions between Gender and some key productive capitals which include GENDER×LANDT, GENDER×CRED and GENDER×CONF.

\section{Results and discussion}

\subsection{Results from the MVP model}

292

Table 2 presents the results obtained from the MVP model for the three silvopastoral practices considered

293 in this study (introduced pastures, shrub removal, and fencing/enclosure). The impact of the different

294 predictors on our model is discussed in the following subsection. We can see that only two variables are

295 significantly associated with adoption of all three variables: socio-economic status and membership in a

296 productive organisation. Further, Land tenure is significantly associated with two practices: introduced

297 pastures and removing of shrubs. Gender of the household head is positively associated with the introduced pastures, while household size is associated with manual shrub removals (albeit with a negative coefficient). Finally, off-farm employment is associated with manual shrub removal while literacy is positively associated with fencing.

Table 2: Results of the multivariate probit model analysis

\begin{tabular}{lccc} 
VARIABLES & $\mathrm{P}$ & $\mathrm{M}$ & $\mathrm{F}$ \\
\hline \multirow{2}{*}{ MUNI1 } & & & \\
& 0.294 & 0.334 & $0.434^{*}$ \\
GENDER & $(0.242)$ & $(0.240)$ & $(0.246)$ \\
& $0.348^{* *}$ & 0.234 & $0.291^{*}$ \\
DIST & $(0.167)$ & $(0.157)$ & $(0.176)$ \\
& 0.00370 & $0.00804^{*}$ & 0.000135 \\
AGE & $(0.00447)$ & $(0.00446)$ & $(0.00449)$ \\
& -0.00619 & -0.00161 & 0.00202 \\
YEAR & $(0.00491)$ & $(0.00478)$ & $(0.00493)$ \\
& -0.00215 & -0.00224 & $2.16 \mathrm{e}-05$ \\
SIZE & $(0.00188)$ & $(0.00183)$ & $(0.00191)$ \\
& $-0.0521^{*}$ & $-0.0778^{* * *}$ & -0.00273 \\
LIT & $(0.0307)$ & $(0.0301)$ & $(0.0306)$ \\
& -0.0256 & -0.0604 & $0.703^{* *}$ \\
SES & $(0.278)$ & $(0.256)$ & $(0.285)$ \\
& $1.070^{* * *}$ & $1.069^{* * *}$ & $1.077^{* * *}$ \\
CRED & $(0.403)$ & $(0.384)$ & $(0.398)$ \\
& 0.0716 & 0.198 & $0.566^{* *}$ \\
COW & $(0.250)$ & $(0.236)$ & $(0.268)$ \\
& 1.249 & 1.176 & $1.785^{*}$ \\
OFF & $(0.836)$ & $(0.815)$ & $(1.053)$ \\
& 0.0962 & $0.319^{* *}$ & $0.298^{*}$ \\
& $(0.160)$ & $(0.157)$ & $(0.163)$
\end{tabular}


Understanding the adoption of sustainable silvopastoral practices

$\begin{array}{lccc}\text { LANDT } & \mathbf{0 . 3 7 9 ^ { * * }} & \mathbf{0 . 3 3 6 ^ { * * }} & 0.247 \\ & (0.164) & (0.162) & (0.166) \\ \text { CONFL } & 0.472^{*} & 0.377 & -0.208 \\ & (0.265) & (0.258) & (0.252) \\ \text { SOC } & 0.398^{* * *} & 0.344^{* *} & 0.335^{* *} \\ & (0.144) & (0.141) & (0.148) \\ \text { Constant } & 3.314 & 3.284 & -2.172 \\ & (3.709) & (3.606) & (3.772) \\ \text { Observations } & & \\ & 353 & 353 & 353 \\ & \text { Log likelihood : }-530.54804 & \\ & \text { Wald Chi2: } 88.14 & \\ & \text { Prob > chi2: } 0.0000 & \end{array}$

302

303

304

305

306
Standard errors in parentheses $* * * \mathrm{p}<0.01, * * \mathrm{p}<0.05, * \mathrm{p}<0.1$

\footnotetext{
The models accounting for interactions among the independent variables are presented in Table 3 . The discussion follows in the next subsection.
} 
Understanding the adoption of sustainable silvopastoral practices

Table 3: Results of the multivariate probit model analysis with inclusion of interaction effects

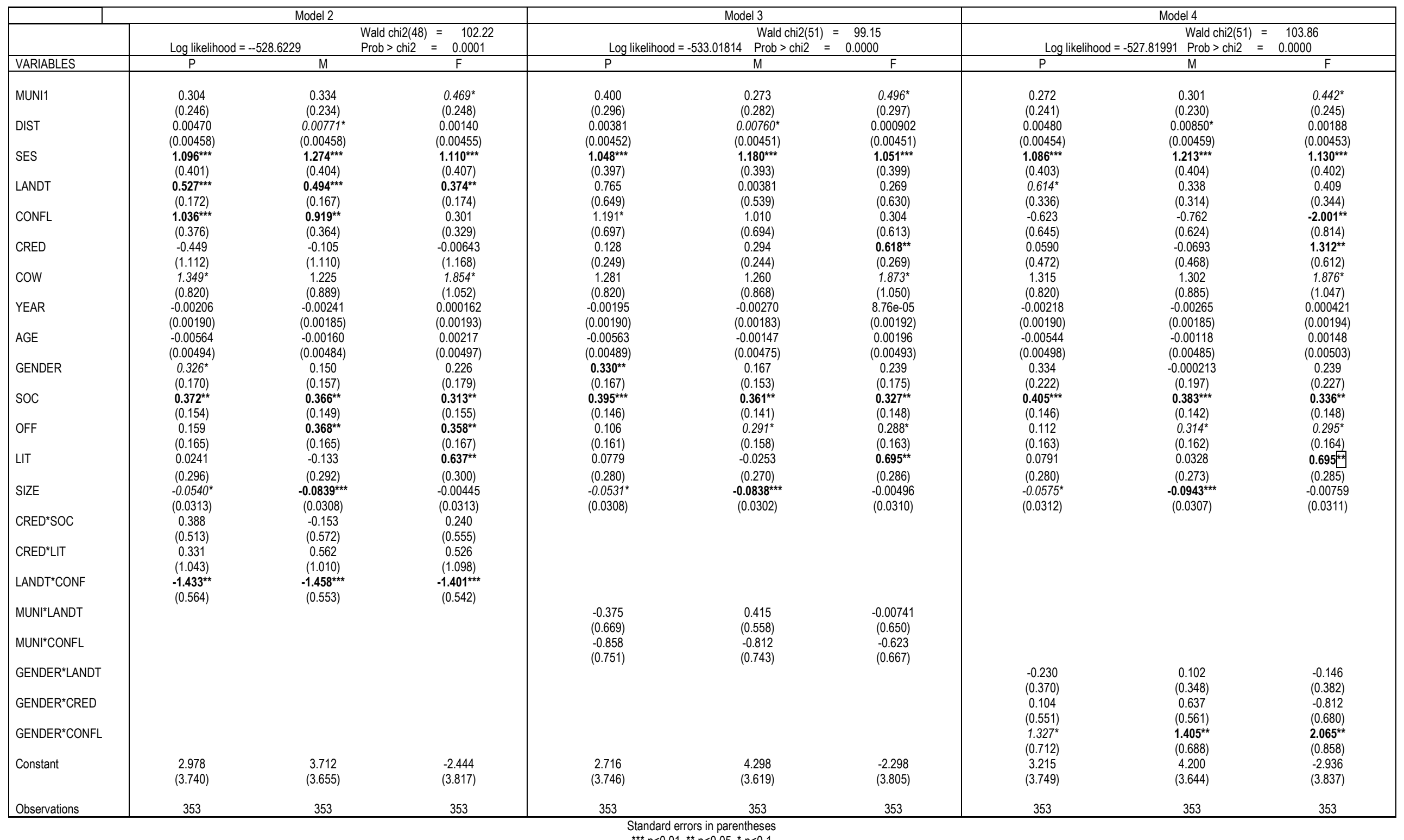




\subsection{Discussion of the most important factors leading to adoption}

311 4.2.1 Distance to the nearest village and age of the household head are associated with adoption 312 Distance to the nearest village has a positive but not statistically significant impact on the adoption of 313 pastures $(\mathrm{P})$ and fencing $(\mathrm{F})$. On the other hand, the manual removal of shrubs $(\mathrm{M})$ is positively associated 314 with distance to the nearest village, albeit only at a $10 \%$ significance level, but consistently in all four models presented. This result is to some extent surprising, as it contradicts our first hypothesis. This would therefore mean, that households that are further away from villages are more likely to adopt those practices. We explored this relationship further in the data, and have not found any cluster that could explain those results, although we noted that the distribution of the distance to the closest village is skewed to the right for households that also adopted removal of shrubs. However, this effect is very small, and only significant with a $10 \% \mathrm{p}$ value threshold. A possible explanation would be that such practice being labour rather than capital intensive, it is more likely to occur in relatively remote areas, where labour is more easily available than capital. Although most available studies do indeed find a negative coefficient associated with distance from nearest village or market (Kassie et al., 2013, 2012; Khataza et al., 2019; Mariano et al., 2012; Wollni et al., 2010), some studies have found a positive relationship between distance to villages or market, in particular for practices that are not based on recent technologies or when there is a cheaper alternative to other available technologies (Arslan et al., 2014; Ndiritu et al., 2014; Teklewold that age is not so important for the adoption of practices in the case examined in our study. However, the results are nonetheless interesting: although non-significant, the negative effect of the household head's age on the adoption of each of the three practices suggests that age might indeed play a certain role in the adoption of agricultural practices, as is often pointed out in the literature (see similar findings in Ndiritu et al. 2014). The lack of significance might be due to other factors determining adoption, such as access to key resources or social capital.

\subsubsection{Socio-economic status, access to credit and subsidies, and social capital are positively} associated with adoption Our socio-economic index is a good predictor of the adoption of multiple agricultural practices. All three practices were positively associated with the index, indicating that wealthier households are more likely to adopt all three practices than poorer households. The number of animals kept by the household is significant as well for some practices, though only at a $10 \%$ threshold. This suggests that wealthier households who are particularly dedicated to cattle production are more likely to adopt all of the practices examined. This result echoes findings from similar studies that were conducted recently on adoption of sustainable practices (Nkegbe and Shankar, 2014; Theriault et al., 2017). A higher socio-economic status can be associated with more available financial resources to be invested in new practices, and it can also be associated with having access to a bank account -a variable not measured in this study, but which is often found to being associated with adoption of new practices. Further some of the assets that compose our index could also be use as collaterals for credit. Access to credit or subsidies is associated with fencing. Ring-fencing a grazing area can be very costly and requires investments that are substantial considering the income of most producers in the region. Access to credit or other financial resources is often mentioned as a factor determining practices adoption in the literature as well (Teklewold et al., 2013a). 
350 Finally, social capital and affiliation with a producer organization is positively associated with all practices. 351 Indeed, this factor is consistently one of the best predictors of adoption of a given practice in our model. 352 This is in line with the literature, where the importance of networks (Banerjee et al., 2013) and local 353 organizations (Kassie et al., 2015; Zeweld et al., 2019) for technology adoption is often emphasized. 354 However, the models that include interaction effects (Table 3) do not show any significant interactions or 355 additive effects between affiliation with an organization and other factors.

$356 \quad$ 4.2.3 Land tenure is (slightly) positively associated with adoption

357 According to our model, secured land tenure is positively associated with two of the three practices 358 examined, namely introduced pastures ( $P$ ) and manual shrub removal (M). However, having secured land 359 tenure is not associated with fencing. This is surprising, as the link between land tenure security and 360 investment in new technologies is strongly supported by previous studies (Amsalu and de Graaff, 2007; 361 Kpadonou et al., 2017; Nkomoki et al., 2018).

362 Usually, the causality behind this association is described as follows: households who have secured land 363 titles or are involved in a process of land tenure regularization might be more inclined to invest in their 364 land because they hope to increase its value, while the risk associated with the investment is low. 365 Economic theory sometimes assumes that land tenure security would result in increased investments in 366 land (see e.g. Hayes et al. 1997, Brasselle et al. 2002); it is sometimes described as having the potential to reduce resource degradation (Landportal, 2019; Perz et al., 2014). However, our interview data as well as preliminary discussions indicate that the direction of causality might not be so clear. Several development projects in our study area require potential beneficiaries to possess official land tenure titles, although some exceptions exist ${ }^{1}$. However, silvopastoral systems in the Chaco can defy conventional wisdom on 373 incentives to invest in management practices or land improvement; but it could also incentivize producers 374 to invest in such practice, for example is labour availability is enhanced, thus incentivizing the investment. 375 These considerations might explain why land tenure is not necessarily associated with a significant 376 coefficient for all practices.

\footnotetext{
${ }^{1}$ One notable exception is the "Bosque nativos y Comunidad" project, which aims to strengthen sustainable management and community structures of local populations in the Chaco in the Province of Salta. However, smallholder communities that access the programme must be located on public land (tierras fiscales).
} 
Understanding the adoption of sustainable silvopastoral practices

4.2.4 However, for two of the three practices considered, land tenure does seem important in explaining their adoption. Securing smallholders' land tenure could thus create important incentives for them to invest in more sustainable production practices. These results are in line with recent research, which also indicates that securing land rights for criollos and indigenous people could have an important effect on biodiversity preservation in the Dry Chaco (Marinaro et al. 2015; Grau et al. 2014; Marinaro et al. 2017). This further highlights potential beneficial effects of land tenure security on slowing down deforestation and habitat loss in this particularly threatened ecoregion (Robinson et al., 2014). We therefore believe that our results could be relevant in other regions of the Argentinian Chaco.

Discussion of interaction effects

The inclusion of interaction effects in the model enhances the model's quality. (see Table 3). While including these interaction effects slightly increases the models' log likelihood, only few of the interactions effects tested are significant. Interestingly, the interaction term between land tenure and conflict has a negative coefficient. This suggests that conflicts over access to land tend to cancel out some potential benefits of secured land tenure. This, in turn, would mean that land tenure can only be an important determinant of the adoption of new, more sustainable practices if other conditions are given - including a conflict-free environment.The interaction between gender and conflict is significant as well, which indicates that women might be more affected by conflicts than men. This result is interesting; in Model 4, conflict alone is either non-significant or has a negative effect on adoption of $F$. This negative effect is then partially mitigated by the head of the household being a male. Other interactions, including the interaction tested for municipality and land tenure proved to be non-significant. At the same time, the slight increase in the log likelihood suggest that including these elements might slightly increase the goodness of fits of our models.

\section{Conclusion}

This study investigated the adoption of selected sustainable silvopastoral practices in the Dry Chaco in the Province of Salta, Argentina. We used a very innovative approach, namely a MVP model, to assess the factors determining adoption of these practices. Our results indicate that adoption is associated with several factors, with social capital, measured through affiliation with a producer organization, being the best predictor of the adoption of multiple practices. Financial resources such as access to credit, as well as the number of animals owned by the households, are also significant predictors of adoption of the selected practices. The effect of securing land tenure is also in general positively associated with the adoption of sustainable silvopastoral practices, although this can be conditional on the existence of conflicts. Because of similar land systems in neighbouring provinces in Argentina and through the Dry Chaco, our results can probably generalize to these areas, although more research could confirm those. These results have major significance for policymaking in the region. They suggest that, securing land tenure for smallholders in the Argentinian Dry Chaco, should be accompanied by a broader process of conflict resolution in order to be fully effective. Our analysis further indicates that collaboration with and support of producer organizations and cooperatives might facilitate the spread of such sustainable management practices. 
Aide, T.M., Clark, M.L., Grau, H.R., López-Carr, D., Levy, M.A., Redo, D., Bonilla-Moheno, M., Riner, G., Andrade-Núñez, M.J., Muñiz, M., 2013. Deforestation and Reforestation of Latin America and the Caribbean (2001-2010). Biotropica 45, 262-271. https://doi.org/10.1111/j.1744-7429.2012.00908.x

Alaggia, F., Cabello, M.J., Carranza, C.A., Cavallero, L., Daniele, G., Erro, M., Ledesma, M., López, D.R., Mussat, E., Navall, M., Peri, P.L., Rusch, V., Sabatini, Á., Saravia, J.J., Echevarría, J.U., Volante, J., 2019. Manual de Indicadores para Monitoreo de Planes Prediales MBGI, INTA. ed. Buenos Aires.

Amsalu, A., de Graaff, J., 2007. Determinants of adoption and continued use of stone terraces for soil and water conservation in an Ethiopian highland watershed. Ecol. Econ. 61, 294-302. https://doi.org/10.1016/j.ecolecon.2006.01.014

Arslan, A., McCarthy, N., Lipper, L., Asfaw, S., Cattaneo, A., 2014. Adoption and intensity of adoption of conservation farming practices in Zambia. Agric. Ecosyst. Environ. 187, 72-86. https://doi.org/10.1016/j.agee.2013.08.017

Banerjee, A., Chandrasekhar, A.G., Duflo, E., Jackson, M.O., 2013. The Diffusion of Microfinance. Science (80-. ). 341, 363-372. https://doi.org/10.1126/science.1236498

Barton, D.N., Benjamin, T., Cerdán, C.R., DeClerck, F., Madsen, A.L., Rusch, G.M., Salazar, Á.G., Sanchez, D., Villanueva, C., 2016. Assessing ecosystem services from multifunctional trees in pastures using Bayesian belief networks. Ecosyst. Serv. 18, 165-174. https://doi.org/10.1016/j.ecoser.2016.03.002

Basurto, X., Ostrom, E., 2009. Beyond the Tragedy of the Commons. Econ. delle fonti di Energ. e dell'ambiente LII, 35-60.

Baudron, F., Corbeels, M., Monicat, F., Giller, K.E., 2009. Cotton expansion and biodiversity loss in African savannahs, opportunities and challenges for conservation agriculture: A review paper based on two case studies. Biodivers. Conserv. 18, 2625-2644. https://doi.org/10.1007/s10531-009-9663-x

Baumgart-Getz, A., Prokopy, L.S., Floress, K., 2012. Why farmers adopt best management practice in the United States: A meta-analysis of the adoption literature. J. Environ. Manage. 96, 17-25. https://doi.org/10.1016/J.JENVMAN.2011.10.006

Bijttebier, J., Ruysschaert, G., Hijbeek, R., Werner, M., Pronk, A.A., Zavattaro, L., Bechini, L., Grignani, C., ten Berge, H., Marchand, F., Wauters, E., 2018. Adoption of non-inversion tillage across Europe: Use of a behavioural approach in understanding decision making of farmers. Land use policy 78, 460-471. https://doi.org/10.1016/j.landusepol.2018.05.044

Borrás, M., Manghi, E., Miñarro, F., Monaco, M., Navall, M., Peri, P., Periago, M.E., Preliasco, P., 2017. Acercando el manejo de bosques con ganadería integrada al monte chaqueño. Una herramienta para lograr una producción compatible con la conservación del bosque. Buenas prácticas para una ganadería sustentable. Kit de extensión para el Gran Chaco. Buenos Aires.

Brasselle, A.-S., Gaspart, F., Platteau, J.-P., 2002. Land tenure security and investment incentives: puzzling evidence from Burkina Faso. J. Dev. Econ. 67, 373-418. https://doi.org/10.1016/S03043878(01)00190-0 
Understanding the adoption of sustainable silvopastoral practices

454

455

456

457

458

459

460

461

462

463

464

465

466

467

468

469

470

471

472

473

474

475

476

477

478

479

480

481

482

483

484

485

486

487

488

489

490

491

Camardelli, M.C., 2005. Estrategias reproductivas y sustentabilidad de sistemas ganaderos criollos del Chaco salteño: el caso de los puesteros criollos del lote fiscal $n^{\circ} 20$ en el departamento Rivadavia. Rev. Interdiscip. Estud. Agrar. 57-93.

Cappellari, L., Jenkins, S.P., 2003. Multivariate Probit Regression using Simulated Maximum Likelihood. Stata J. 3, 278-294. https://doi.org/10.1177/1536867x0300300305

Carr, D.L., Lopez, A.C., Bilsborrow, R.E., 2009. The population, agriculture, and environment nexus in Latin America: country-level evidence from the latter half of the twentieth century. Popul. Environ. 30, 222-246. https://doi.org/10.1007/s11111-009-0090-4

Ceddia, M.G., Zepharovich, E., 2017. Jevons paradox and the loss of natural habitat in the Argentinean Chaco: The impact of the indigenous communities' land titling and the Forest Law in the province of Salta. Land use policy 69, 608-617. https://doi.org/10.1016/J.LANDUSEPOL.2017.09.044

Córdoba, G.S., Camardelli, M.C., 2017. Caracteristicas socioeconomicas del sitio piloto de degradacion de tierras y desertificacion ( ONDTYD ). Breves Contrib. del I.E.G 28, 61-90.

de Graaff, J., Amsalu, A., Bodnár, F., Kessler, A., Posthumus, H., Tenge, A., 2008. Factors influencing adoption and continued use of long-term soil and water conservation measures in five developing countries. Appl. Geogr. 28, 271-280. https://doi.org/10.1016/j.apgeog.2008.05.001

Doss, C.R., Morris, M.L., 2001. How does gender affect the adoption of agricultural innovations?: The case of improved maize technology in Ghana. Agric. Econ. 25, 27-39. https://doi.org/10.1016/S0169-5150(00)00096-7

Feder, G., 1982. Adoption of Interrelated Agricultural Innovations: Complementarity and the Impacts of Risk, Scale, and Credit. Am. J. Agric. Econ. 64, 94-101. https://doi.org/10.2307/1241177

Fehlenberg, V., Baumann, M., Gasparri, N.I., Piquer-Rodriguez, M., Gavier-Pizarro, G., Kuemmerle, T., 2017. The role of soybean production as an underlying driver of deforestation in the South American Chaco. Glob. Environ. Chang. 45, 24-34. https://doi.org/10.1016/j.gloenvcha.2017.05.001

Fernández Milmanda, B., Garay, C., 2019. Subnational variation in forest protection in the Argentine Chaco. World Dev. 118, 79-90. https://doi.org/10.1016/j.worlddev.2019.02.002

Ferreira Gonzaga, J., Vilpoux, O.F., Gomes Pereira, M.W., 2019. Factors influencing technological practices in the Brazilian agrarian reform. Land use policy 80, 150-162. https://doi.org/10.1016/j.landusepol.2018.10.005

Filmer L. Pritchett, D., 1998. The Effect of Household Wealth on Educational Attainment Around the World: Demographic and Health Survey Evidence.

Filmer, D., Pritchett, L.H., 2001. Estimating Wealth Effects Without Expenditure Data-or Tears: an Application to Educational Enrolments in States of India. Demography 38, 115-132.

Garbach, K., Lubell, M., DeClerck, F.A.J., 2012. Payment for Ecosystem Services: The roles of positive incentives and information sharing in stimulating adoption of silvopastoral conservation practices. Agric. Ecosyst. Environ. 156, 27-36. https://doi.org/10.1016/j.agee.2012.04.017

Grau, H.R., Gasparri, N.I., Aide, T.M., 2008. Balancing food production and nature conservation in the 
Understanding the adoption of sustainable silvopastoral practices

Neotropical dry forests of northern Argentina. Glob. Chang. Biol. 14, 985-997. https://doi.org/10.1111/j.1365-2486.2008.01554.x

Grau, H.R., Torres, R., Gasparri, N.I., Blendinger, P.G., Marinaro, S., Macchi, L., 2015. Natural grasslands in the Chaco. A neglected ecosystem under threat by agriculture expansion and forest-oriented conservation policies. J. Arid Environ. 123, 40-46. https://doi.org/10.1016/J.JARIDENV.2014.12.006

Hänsela, G., Ibrahimb, M., Villanuevab, C., Andradec, H.J., 2009. Exploiting synergies between silvopastoral system components for carbon sequestration and an increase in cattle productivity : experience from Costa Rica and Nicaragua. XIII World For. Congr. 11.

Hardin, G., 1968. The Tragedy of the Commons. Science (80-. ). 162, 1243-1248. https://doi.org/10.1126/science.162.3859.1243

Harris, N.L., Brown, S., Hagen, S.C., Saatchi, S.S., Petrova, S., Salas, W., Hansen, M.C., Potapov, P. V, Lotsch, A., 2012. Baseline map of carbon emissions from deforestation in tropical regions. Science 336, 1573-6. https://doi.org/10.1126/science.1217962

Hayes, J., Roth, M., Zepeda, L., 1997. Tenure Security, Investment and Productivity in Gambian Agriculture: A Generalized Probit Analysis. Am. J. Agric. Econ. 79, 369-382. https://doi.org/10.2307/1244136

Kassie, M., Jaleta, M., Shiferaw, B., Mmbando, F., Mekuria, M., 2013. Adoption of interrelated sustainable agricultural practices in smallholder systems: Evidence from rural Tanzania. Technol. Forecast. Soc. Change 80, 525-540. https://doi.org/10.1016/j.techfore.2012.08.007

Kassie, M., Jaleta, M., Shiferaw, B., Mmbando, F., Mekuria, M., 2012. Interdependence of farmer technology adoption decisions in smallholder systems: joint estimations of investments in sustainable agricultural practices in rural Tanzania. Foz do Iguaçu, 254, 18-24. https://doi.org/110.5923/sgem2012/s1.169

Kassie, M., Teklewold, H., Jaleta, M., Marenya, P., Erenstein, O., 2015. Understanding the adoption of a portfolio of sustainable intensification practices in eastern and southern Africa. Land use policy 42, 400-411. https://doi.org/10.1016/j.landusepol.2014.08.016

Khataza, R.R.B., Hailu, A., Doole, G.J., Kragt, M.E., Alene, A.D., 2019. Examining the relationship between farm size and productive efficiency: a Bayesian directional distance function approach. Agric. Econ. (United Kingdom) 50, 237-246. https://doi.org/10.1111/agec.12480

Kleemann, L., Abdulai, A., Buss, M., 2014. Certification and access to export markets: Adoption and return on investment of organic-certified pineapple farming in Ghana. World Dev. 64, 79-92. https://doi.org/10.1016/j.worlddev.2014.05.005

Knowler, D., Bradshaw, B., 2007. Farmers' adoption of conservation agriculture: A review and synthesis of recent research. Food Policy 32, 25-48. https://doi.org/10.1016/j.foodpol.2006.01.003

Kolenikov, S., Angeles, G., 2009. Socioeconomic Status Measurement With Discrete Proxy Variables: Is Principal Component Analysis a Reliable Answer? Rev. Income Wealth 55, 128-165. https://doi.org/10.1111/j.1475-4991.2008.00309.x

Kolenikov, S., Angeles, G., 2004. The Use of Discrete Data in PCA: Theory, Simulations, and Applications to Socioeconomic Indices. Chapel Hill Carolina Popul. Center, Univ. North Carolina. 1-59. 
Understanding the adoption of sustainable silvopastoral practices

Kpadonou, R.A.B., Owiyo, T., Barbier, B., Denton, F., Rutabingwa, F., Kiema, A., 2017. Advancing climatesmart-agriculture in developing drylands: Joint analysis of the adoption of multiple on-farm soil and water conservation technologies in West African Sahel. Land use policy 61, 196-207. https://doi.org/10.1016/j.landusepol.2016.10.050

Landportal, 2019. 'Giving land tenure rights to commons can prevent degradation' | Land Portal | Securing Land Rights Through Open Data [WWW Document]. Landportal news. URL https://landportal.org/news/2019/09/'giving-land-tenure-rights-commons-can-preventdegradation' (accessed 9.27.19).

Latawiec, A.E., Strassburg, B.B.N., Silva, D., Alves-pinto, H.N., Feltran-barbieri, R., Castro, A., Iribarrem, A., Cordeiro, M., Amin, K., Kalif, B., Gardner, T., Beduschi, F., 2017. Agriculture , Ecosystems and Environment Improving land management in Brazil : A perspective from producers. "Agriculture, Ecosyst. Environ. 240, 276-286. https://doi.org/10.1016/j.agee.2017.01.043

le Polain de Waroux, Y., Baumann, M., Gasparri, N.I., Gavier-Pizarro, G., Godar, J., Kuemmerle, T., Müller, R., Vázquez, F., Volante, J.N., Meyfroidt, P., 2017. Rents, Actors, and the Expansion of Commodity Frontiers in the Gran Chaco. Ann. Am. Assoc. Geogr. 108, 204-225. https://doi.org/10.1080/24694452.2017.1360761

Mariano, M.J., Villano, R., Fleming, E., 2012. Factors influencing farmers' adoption of modern rice technologies and good management practices in the Philippines. Agric. Syst. 110, 41-53. https://doi.org/10.1016/j.agsy.2012.03.010

Marinaro, S., Grau, H.R., Gasparri, N.I., Kuemmerle, T., Baumann, M., 2017. Differences in production, carbon stocks and biodiversity outcomes of land tenure regimes in the Argentine Dry Chaco. Environ. Res. Lett. 12, 045003. https://doi.org/10.1088/1748-9326/aa625c

Marinaro, S., Grau, H.R., Macchi, L., Zelaya, P. V., 2015. Land tenure and biological communities in dry Chaco forests of northern Argentina. J. Arid Environ. 123, 60-67. https://doi.org/10.1016/j.jaridenv.2014.06.005

Marinaro, S., Grau, H.R., Macchi, L., Zelaya, P. V, 2014. Land tenure and biological communities in dry Chaco forests of northern Land tenure and biological communities in dry Chaco forests of northern Argentina. J. Arid Environ. 123, 60-67. https://doi.org/10.1016/j.jaridenv.2014.06.005

Mastrangelo, M.E., Sun, Z., Seghezzo, L., Müller, D., 2019. Survey-based modeling of land-use intensity in agricultural frontiers of the Argentine dry Chaco. Land use policy 88, 104183. https://doi.org/10.1016/j.landusepol.2019.104183

Ndiritu, S.W., Kassie, M., Shiferaw, B., 2014. Are there systematic gender differences in the adoption of sustainable agricultural intensification practices? Evidence from Kenya. Food Policy 49, 117-127. https://doi.org/10.1016/j.foodpol.2014.06.010

Nieto, M.I., Barrantes, O., Privitello, L., Reiné, R., 2018. Effects of the management of extensive beef grazing systems on the mitigation of greenhouse gas emissions in semi-arid rangelands of central. Sustainability 10, 2-22. https://doi.org/10.3390/su10114228

Nigussie, Z., Tsunekawa, A., Haregeweyn, N., Adgo, E., Nohmi, M., Tsubo, M., Aklog, D., Meshesha, D.T., Abele, S., 2017. Factors influencing small-scale farmers' adoption of sustainable land management technologies in north-western Ethiopia. Land use policy 67, 57-64. 
Understanding the adoption of sustainable silvopastoral practices

https://doi.org/10.1016/j.landusepol.2017.05.024

Nkegbe, P.K., Shankar, B., 2014. Adoption intensity of soil and water conservation practices by smallholders: evidence from Northern Ghana. Bio-based Appl. Econ. 3, 159-174. https://doi.org/10.13128/bae-13246

Nkegbe, P.K., Shankar, B., Ceddia, G., 2012. Smallholder adoption of soil and water conservation techniques in Ghana. J. Agric. Sci. Technol. B 595-605. https://doi.org/10.5897/AJAR2013.7952

Nkomoki, W., Bavorová, M., Banout, J., 2018. Adoption of sustainable agricultural practices and food security threats: Effects of land tenure in Zambia. Land use policy 78, 532-538. https://doi.org/10.1016/j.landusepol.2018.07.021

Peri, P.L., Fermani, S., Mónaco, M., Rosales, V., Díaz, F., Collado, L., Torres, S.C., Ceballos, E., Soupet, J., Perdomo, M., Castelló, A.S., Antequera, S., 2018. Management of forests with integrated livestock (MBGI) in Argentina, in: Rusch, V. (Ed.), IV Congreso Nacional de Sistemas Silvopastoriles. INTA Ediciones, Neuquen, pp. 724-742.

Perz, S., Barnes, G., Shenkin, A., Rojas, D., Vaca, C., 2014. Private and communal lands? The ramifications of ambiguous resource tenure and regional integration in Northern Bolivia. Int. J. Commons 8, 179206.

Piquer-Rodríguez, M., Butsic, V., Gärtner, P., Macchi, L., Baumann, M., Gavier Pizarro, G., Volante, J.N., Gasparri, I.N., Kuemmerle, T., 2018. Drivers of agricultural land-use change in the Argentine Pampas and Chaco regions. J. Appl. Geogr. 91, 111-122. https://doi.org/10.1016/j.apgeog.2018.01.004

Robinson, B.E., Holland, M.B., Naughton-Treves, L., 2014. Does secure land tenure save forests? A metaanalysis of the relationship between land tenure and tropical deforestation. Glob. Environ. Chang. 29, 281-293. https://doi.org/10.1016/J.GLOENVCHA.2013.05.012

Rogers, E.M., 2003. Diffusion of innovations, 5th ed. ed. Free Press, New York.

Shetto, R. ed., Owenya, M. ed., 2007. Conservation agriculture as practised in Tanzania: three case studies. African Conservation Tillage Network, Centre de Coopération Internationale de Recherche Agronomique pour le Développement, Food and Agriculture Organization of the United Nations., Nairobi.

Shukla, P.R., Skea, J., Buendia, E.C., Masson-Delmotte, V., Pörtner, H.-O., Roberts, D.C., Zhai, P., Slade, R., Connors, S., Diemen, R. van, Ferrat, M., Haughey, E., Luz, S., Neogi, S., Pathak, M., Petzold, J., Portugal, J., Pereira, J., Vyas, P., Huntley, E., Kissick, K., Belkacemi, M., Malley, J., 2019. Climate Change and Land: an IPCC special report on climate change, desertification, land degradation, sustainable land management, food security, and greenhouse gas fluxes in terrestrial ecosystems. IPCC, Geneva.

Smith, A., Snapp, S., Chikowo, R., Thorne, P., Bekunda, M., Glover, J., 2017. Measuring sustainable intensification in smallholder agroecosystems: A review. Glob. Food Sec. 12, 127-138. https://doi.org/10.1016/j.gfs.2016.11.002

Teklewold, H., Kassie, M., Shiferaw, B., 2013a. Adoption of multiple sustainable agricultural practices in rural Ethiopia. J. Agric. Econ. 64, 597-623. https://doi.org/10.1111/1477-9552.12011

Teklewold, H., Kassie, M., Shiferaw, B., Köhlin, G., 2013b. Cropping system diversification, conservation 
Understanding the adoption of sustainable silvopastoral practices

625

626

627

628

629

630

631

632

633

634

635

636

637 tillage and modern seed adoption in Ethiopia: Impacts on household income, agrochemical use and demand for labor. Ecol. Econ. 93, 85-93. https://doi.org/10.1016/j.ecolecon.2013.05.002

Tenge, A., Graaff, J. De, Hella, J., 2004. Social and economic factors affecting the adoption of soil and water conservation in West Usambara highlands, Tanzania. L. Degrad. 114, 177.

Therburg, A., Corso, M.L., Stamati, M., Bottero, C., Lizana, P., Pietragalla, V., 2019. Síntesis de Resultados de la Evaluación de la Degradación de Tierras: 2012-2017. IADIZA, Mendoza.

Theriault, V., Smale, M., Haider, H., 2017. How Does Gender Affect Sustainable Intensification of Cereal Production in the West African Sahel? Evidence from Burkina Faso. World Dev. 92, 177-191. https://doi.org/10.1016/j.worlddev.2016.12.003

Volante, J.N., Mosciaro, M.J., Gavier-Pizarro, G.I., Paruelo, J.M., 2016. Agricultural expansion in the Semiarid Chaco: Poorly selective contagious advance. Land use policy 55, 154-165. https://doi.org/10.1016/j.landusepol.2016.03.025

Ward, P.S., Bell, A.R., Droppelmann, K., Benton, T.G., 2018. Early adoption of conservation agriculture practices: Understanding partial compliance in programs with multiple adoption decisions. Land use policy 70, 27-37. https://doi.org/10.1016/j.landusepol.2017.10.001

Wauters, E., Bielders, C., Poesen, J., Govers, G., Mathijs, E., 2010. Adoption of soil conservation practices in Belgium: An examination of the theory of planned behaviour in the agri-environmental domain. Land use policy 27, 86-94. https://doi.org/10.1016/j.landusepol.2009.02.009

Wollni, M., Lee, D.R., Thies, J.E., 2010. Conservation agriculture, organic marketing, and collective action in the Honduran hillsides. Agric. Econ. 41, 373-384. https://doi.org/10.1111/j.15740862.2010.00445.x

Wright, J., 2009. Sustainable agriculture and food security in an era of oil scarcity : lessons from Cuba. Earthscan, London.

Zeweld, W., Van Huylenbroeck, G., Tesfay, G., Azadi, H., Speelman, S., 2019. Sustainable agricultural practices, environmental risk mitigation and livelihood improvements: Empirical evidence from Northern Ethiopia. Land use policy In Press. https://doi.org/10.1016/j.landusepol.2019.01.002 
638 Annex A: Variables included in the model and weights given by the Polychoric principle component 639 analysis

640 A socio-economic index was created by using a Polychoric Principal Component Analysis (PPCA) on a 641 vector of socio-economic variables in our surveys, following a procedure first established by Filmer and 642 Pritchett (Filmer and Pritchett, 1998). We used to conduct the Principle component analysis on a 643 polychoric correlation matrix, in order to improve the model, as suggested by Kolenikov and Angeles 644 (Kolenikov and Angeles, 2009). There were 10 variables considered for the index. The PPCA returns the 645 weight given to each variable in our index, which correspond to the loadings of the first component.

\begin{tabular}{|l|l|l|l|}
\hline Name of variable & Description & Type & Weight (loading PC1s) \\
\hline HOUSE2 & 1 if household owns another house & binary & $0.56(0.50)$ \\
\hline FLUSH & 1 if household has toilets with a flush & binary & $0.04(0.19)$ \\
\hline ENERGY & 1 if household has electricity (or a generator) & binary & $0.34(0.48)$ \\
\hline ROOF & $\begin{array}{l}1 \text { if house has a roof made of solid material } \\
\text { (clay tiles, wood, or metal) }\end{array}$ & binary & $0.65(0.48)$ \\
\hline TV & 1 if household has television & binary & $0.09(0.28)$ \\
\hline FRIDGE & 1 if household has a refrigerator & binary & $0.36(0.48)$ \\
\hline WM & 1 if household has a washing machine & binary & $0.09(0.29)$ \\
\hline TRUCK & 1 if household has a pickup truck & binary & $0.18(0.38)$ \\
\hline MBIKE & 1 if household has a motorcycle & binary & $0.82(0.39)$ \\
\hline BIKE & 1 if household has a bicycle & binary & $0.44(0.50)$ \\
\hline
\end{tabular}

